\title{
Technology Entrepreneurship and the Performance of Enterprises in the Conditions of Covid-19 Pandemic: The Fuzzy Set Analysis of Waste to Energy Enterprises in Poland
}

\author{
Piotr Kordel * and Radosław Wolniak *
}

check for

updates

Citation: Kordel, P.; Wolniak, R. Technology Entrepreneurship and the Performance of Enterprises in the Conditions of Covid-19 Pandemic: The Fuzzy Set Analysis of Waste to Energy Enterprises in Poland. Energies 2021, 14, 3891. https:// doi.org/10.3390/en14133891

Academic Editors: Wieslaw Urban and Wen-Hsien Tsai

Received: 26 April 2021

Accepted: 24 June 2021

Published: 28 June 2021

Publisher's Note: MDPI stays neutral with regard to jurisdictional claims in published maps and institutional affiliations.

Copyright: (c) 2021 by the authors. Licensee MDPI, Basel, Switzerland. This article is an open access article distributed under the terms and conditions of the Creative Commons Attribution (CC BY) license (https:// creativecommons.org/licenses/by/ $4.0 /)$.
Organization and Management Department, Silesian University of Technology, 41-800 Zabrze, Poland

* Correspondence: radoslaw.wolniak@polsl.pl (R.W.); piotr.kordel@polsl.pl (P.K.); Tel.: +48-607-593-052 (P.K.)

\begin{abstract}
This article's aim is to explain the impact of technology entrepreneurship phenomenon on waste management enterprise performance in the conditions of COVID-19 pandemic. The concept of technology entrepreneurship according to the configuration approach and the category of highperformance organization are the theoretical bases of empirical investigation. For the implementation of empirical research, Fuzzy set Qualitative Comparative Analysis (FsQCA) was adopted. The research sample included a group of producers of Refused Derived Fuel (RDF) as a central part of the waste to energy industry located in Poland. The research results showed that the waste to energy sector is highly immune to pandemic threats. While during COVID-19, the basic economic parameters (i.e., sales, profitability and employment) of the entire industry in Poland clearly decreased, the same parameters in the case of the waste to energy industry remained at the same level. The research results allow the formulation of two high-performance models of technology entrepreneurship in the waste to energy industry under COVID-19 conditions. The first model is based on traditional technologies and hierarchical organizational structures, and the second is using innovative technologies and flexible structures. Both technology entrepreneurship models are determined by their emergence as complementary to implementation strategies and the opportunity-oriented allocation of resources within business model portfolios.
\end{abstract}

Keywords: technology entrepreneurship; waste management industry in Poland; COVID-19 pandemic; QCA; waste management

\section{Introduction}

Nowadays, the ongoing COVID-19 pandemic has influenced many sectors of business and many types of business activities [1-8]. Additionally, entrepreneurship has changed due to pandemic conditions [9]. The pandemic affected entrepreneurship because it requires some form of engagement with society. Because of COVID-19, organizations are changing into more digital entities with remote work and web-based teams [10-12]. The entrepreneurships in those conditions move towards digital entrepreneurship. Digital entrepreneurship was already widespread after the pandemic, but COVID-19 has influenced entrepreneurs to try to work in a totally digital environment [13-17].

Technological entrepreneurship has an important role in the process of creating a regional economy. When there are many technological organizations in a region, and the level of technological entrepreneurship is high, it has a positive impact on the region in which the organizations exist [18-21]. Based on that assumption, governments should to emphasise the level of entrepreneurship among students, engineers and managers which can lead into the increase of technological entrepreneurship in the future [22,23]. The possibility of creating new, innovative technological solutions is very important for the organizations and economy [24-27].

We think that it is especially important in the waste to energy market. This can be a very important part of creating solutions towards transformation of the economy towards a 
circular economy. In industrialized countries we face a big challenge connected with quickly and safely depositing the growing amount of waste $[28,29]$. Waste to energy is one of the very important circular economy solutions which have social, economic and environmental positive effects because of better usage of natural resources, potential job creation, reduction of emission amounts and also fostering innovations [30]. This last point is especially important from this paper's point of view. We think that waste to energy organizations can foster innovation in a circular economy, but it needs technology entrepreneurship. Rada, in his paper, points out many consequences of the circular economy on the waste to energy market and the process of plant designing [31].

Waste to energy facilities can lead to positive environmental and economic effects [32]. In particular, plants operating in the waste to energy market can be recommended in urban areas in big agglomerations, because in those places there is not sufficient space for the installation of biological treatment dedicated for municipal waste [33,34]. However, we think that for increasing the waste to energy market, it is not sufficient to have access to new technological solutions, but we also need a sufficient level of technology entrepreneurship. Without this entrepreneurship, it is not easy to implement new technological solutions. On this basis, we think that is worth analysing the impact of technology entrepreneurship on the waste to energy market and identifying those technology entrepreneurship configurations which have a positive effect on the development of waste to energy organizations.

On the basis of literature analysis, we found that relations between technology entrepreneurship and the COVID-19 pandemic are not well known. This was the research gap on the basis of which we chose our research area. In particular, there is not research about the impact on entrepreneurship in the waste to energy sector. It is interesting to know those relations from scientific and practical point of view.

On the basis of this research gap, we have established our research aim, which is to explain the impact of technology entrepreneurship phenomenon on waste management enterprise performance in the conditions of the COVID-19 pandemic.

\section{Literature Analysis}

Technology entrepreneurship is something that facilitate functioning and prosperity of firms, individuals, regions and nations [23,35-37]. Nowadays it has very big impact on the economy, and this is the reason it is worth studying and analyzing [38,39]. The process of creating technological entrepreneurship itself is based largely on endogenous factors of the organization. For important factors, we can include: expertise and qualifications of employees and also their ability to implement those innovative solutions into practice in their organizations $[9,16]$. Entrepreneurs are able to be proactive and able to anticipate. They should to build a credible vision of their own business [40-42]. In the case of technology, entrepreneur organizations should to understand their business environment, their technology, and also have the ability to know the influence of ecosystem components on new venture strategies [43-46].

The concept of technology entrepreneurship has many definitions described in the literature [47-50]. Technology entrepreneurship exists when a new development in science and/or engineering constitutes a core element of the opportunity that can enable the emergence of new market, cluster, venture or industry [51-53]. The new development may lead to a new business model based on first-mover advantages, network effects, technical standards and declining costs [54,55].

In Table 1, we present some often-used definitions from important international papers. 
Table 1. The main definitions of technology entrepreneurship.

\begin{tabular}{|c|c|}
\hline Author & Definition \\
\hline Jones-Evans (1995) & The establishment of a new technology venture \\
\hline Jelinek (1996) & $\begin{array}{c}\text { Efforts to interpret data which are ambiguous to } \\
\text { sustain technology efforts and coordinated } \\
\text { persistent endeavors used to accomplish } \\
\text { technological change. }\end{array}$ \\
\hline Venkataraman and Sarasvathy (2001) & Solutions used in search of problems \\
\hline Nicholas and Armstrong (2003) & $\begin{array}{l}\text { Organization risk bearing and management in } \\
\text { technology based businesses }\end{array}$ \\
\hline Graud and Karnøe (2003) & $\begin{array}{l}\text { An agency that can be distributed across different } \\
\text { kinds of actors. Each of them is involved with a } \\
\text { technology and also in the process can generate } \\
\text { inputs resulting in transformation of an new, } \\
\text { emerging technologies. }\end{array}$ \\
\hline Liu (2005) & $\begin{array}{c}\text { Ways in which entrepreneurs can draw on } \\
\text { structures and resources to exploit opportunities in } \\
\text { emerging technologies } \\
\text { to sustain technology efforts and coordinated } \\
\text { persisted endeavor used to accomplish } \\
\text { technological change. }\end{array}$ \\
\hline
\end{tabular}

Technological entrepreneurship is a style of business leadership that involves factors as:

Dorf and Byers (2005) human resource high-potential capitalization, identification, managing accelerated growth, technology intensive commercial opportunities and significant risk taking.

Abdullah and Ahcene (2011)

Technology entrepreneurship can be understood as the integration of technological and entrepreneurial realms.

Technology entrepreneurship is an investment in a project. This investment assembles and deploys specialized heterogeneous assets and individuals

Bailetti (2012) which are intricately related to the new conceptions in scientific and technological

knowledge. The purpose of the activity is creation and capturing additional value for a firm.

Technological entrepreneurship occurs when the development of science and engineering creates a key element of an entrepreneurial opportunity,

Beckman, Eisenhardt, Kotha, Meyer, Rajagopolan, (2012) enabling the generation of a given venture, market, cluster or even the entire industry

Source: on basis: [1-7,11,19-21,56,57].

The definitions presented in Table 1 suggest that entrepreneurship technology is connected with small rather than big organizations and concentrates on launching and introducing new ventures, products and applications [56,57]. On the basis of the presented definitions, we can propose our definition of entrepreneurship technology which corresponds with our research. Technological entrepreneurship is defined as the specific configuration of strategy and organizational structure around the core of new technologies. A key feature of the organizational configuration of technological entrepreneurship is the ability to dynamically allocate resources within a constantly created portfolio of business models as a response to unpredictable changes in the environment.

Very interesting analysis of the technology entrepreneurship concept was presented by T. Bailetti [58]. He has undertaken a deep analysis of the articles on technology en- 
trepreneurship published from 1970 to identify the various types of definition of the technology entrepreneurship concept, and topics related with this concept, which were in the papers.

Bailetti's analysis literature about technology entrepreneurship has determined the following main findings about the topic especially often described in international papers [58]:

- the literature about entrepreneurship concentrates on the topic of technology firm formations;

- the main part of the literature concentrates rather on small technology organizations, not mid-sized or large firms [59];

- especially often, papers concentrated on the topic of external factors influencing the formation of technology organizations;

- additionally, some papers describe the influence of technology entrepreneurship on regional development;

- $\quad$ very rarely, papers about technology entrepreneurship contribute to the other fields such as economics, management, etc.

Badzińska thinks [60] that the process of creating technological entrepreneurship in a company is an effect of joint achievements of team work which offer support, expertise and knowledge. To achieve successful effects in the field of technological entrepreneurship, an employee should have a tendency to take risks and actions which are concentrated on continuous development [38,39]. Managers should manifest the characteristics of a leader who is open to innovativeness.

The technology entrepreneurship is especially important when we deal with highperformance organizations. The main concept of high-performance organizations was presented by de Wall [61]. He analyzed the impact of the financial crisis and economic downturn (2007-2010) on the functioning of the business world. On the basis of his analysis he tried to identify factors that determined sustainable organizational success in times of economic downturn. This is very interesting, because now we are in the times of another economic downturn due to the COVID-19 pandemic.

The high-performance organizations are organizations whose long-term performance is better than in the case of comparable organizations [62-64]. There are many definitions of high-performance organizations but they have the common components as following: employee involvement, participation, empowerment, self-managing work teams, use of total quality management concepts, learning organization and integrated production technologies $[65,66]$.

High-performance organizations lead the way and do not perform better because of only technical or human resources reasons [67-69]. Their success is based on a set of factors which should operate together to achieve the effect of synergy [70,71].

The main high-performance organization factors are [61]:

- autonomy,

- continuous improvement and renewal,

- management quality,

- workforce quality,

- long-term orientation.

In our paper we used the configurational approach to organization. The concept of configuration can be viewed from a systemic perspective. The organization in this concept should be viewed as a constellation of interconnected elements and is one of the central ideas in many organization studies. It can be dated back to the emergence of systemic thinking [72]. The term organizational configuration can be used to denote a multidimensional constellation of conceptually distinctive characters that can commonly occur together [73].

The problems with the rise of configurational theories were connected with: complexity that can grow exponentially when more elements are added to the system, the need 
to develop a theory that can deal with the complexity of configuration and methodology that can account for the complexity of interconnected elements which can bring outcomes synergistically and jointly rather than individually [74].

The starting point to resolve those problems was connected with the emergence of set of configurational theoretical methods, especially Qualitative Comparative Analysis (QCA) and the possibility of its use in social sciences. The method itself has its origins in the tradition of the use comparative methods in social sciences and using this method can be transformed into a systematized and developed approach. Especially the conception of the usage of Qualitative Comparative Analysis was developed and described by C. Ragin [75-77] and next the conception was improved by other scientists [78,79].

The conception of Qualitative Comparative Analysis was developed as a link between the case-oriented approaches (qualitative approaches) and variable-oriented approaches (quantitative approaches). The use of conception provides the researcher a novel set of tools useful for disentangling many complex casual relationships. The method has its ability to be used to understand the configurational nature of a limited set of cases. The method can be especially attractive in the case in the field of organization and management. This is because the organization is a cluster of interconnected practices and structures and not something of which all components can be easily understood in isolation $[80,81]$.

A very important part of our analysis is connected with the waste to energy industry. The waste to energy concept can be defined as a process used to recover energy from waste by treating and using and it in the form of transport fuel, electricity or heat $[82,83]$. In European Union countries, Schiffer thinks that biological treatment of waste has the most potential to grow and this technology can be, in the future, commercially viable [11]. The waste to energy conception is a part of municipal waste management. This is an important area which is in the European Commission's interest. This area has significant impact on the plan for transformation towards a circular economy [32].

Psomopulos describes positive experiences with waste to energy implementation in the USA. He points out that waste to energy can be a good and relevant source of renewable energy. With a good level of maintenance, a waste to energy plant can last about 30 years. Compared the amount of land needed for landfilling, the waste to energy plant needs a much lower amount of land, and because of that the initial capital for land is very small $[84,85]$. In another paper, Psomopoulos also describes the positive effects of using waste management methods in EU countries. The EU now promotes energy recovery using thermal treatment that leads to providing electricity and heat to industrial, domestic and commercial consumers and also can have a positive effect in eliminating the amount of waste to be landfilled [86]. In EU countries the most widespread technology for waste to energy is grate combustion. Using this technology, thermal energy can be recovered and in this way heat is converted to electricity [87]. Psomopoulos in his paper has described many valuable examples from EU countries about using various types of waste to energy approaches in many EU cities. He, based on his research, points out that waste is a very valuable source of energy and materials. The highest priority in waste to energy usage is reuse and also recycling, combined with source separation. All analyzed cities used various methods of energy recovery from waste. The usage of energy from waste is also a very important factor towards sustainable city development [87]. Other examples of successful implementation of waste to energy projects are described by Kumarasi and Dissanayke. They found that the stakeholders' involvement is a very indispensable element in the successful implementation of waste to energy conceptions in business [88]. They can influence a new waste to energy project and contribute by source reduction and helping with cooperation with civil bodies and identification of potential waste to energy technologies and facilities. Stakeholders can also impact on implementing environmental standards and regulations, which are important for waste to energy companies. Moreover, they apply pressure on implementing environmental policies and standards [88]. The good level of economic efficiency of using waste to energy technology is also described by Wen-Tsa $[89,90]$. He points out that using of waste to energy is a win-win approach. 
This technology can generate a good amount of electricity, and also decrease dependence on imported fossil fuels and greenhouse gas emissions [89,91]. Further, Zhao described positive economic effects of using waste to energy technology in China [92]. We can observe the same positive effects in many European Union-related researches [93-96].

Amongst the EU countries and organizations which contribute to waste to energy development is CEWP-The Confederation of European Waste-To-Energy Plants. This organization is an umbrella association of many international and national operators of waste to energy. It represents 410 plants which operate in 23 countries. Those organizations make up about $80 \%$ of the waste to energy market in Europe [97]. According to CEWP, waste to energy is an important factor in the way towards a circular economy. Now, the current capacity of EU plants in the case of waste to energy is about 90 million tones, and it will increase significantly in the following years [98]. In addition, it needs to be underlined that the broader usage of renewable energy paves the way towards decarbonisation of the economy. The production of energy from waste leads to significant saveings in greenhouse gas emissions, because this type of energy can replace traditional energy from fossil fuels; also very important is the organic (biodegradable) part of waste input [99,100].

Further, we can find in the literature analysis about problems in the process of implementing a waste to energy strategy. For example, Vujic describe some barriers connected with implementation of this strategy in developing countries. He points out problems connected with [101]:

- lack of good distinctions between city ownership and state,

- problems with job positions,

- problems with corruption in the country which can have negative impact on waste to energy projects,

- lack of sufficient sources of investment,

- problems connected with low capacity needed for new legislation implementation,

- problems with sufficient capacity of local government and ministries.

The waste to energy market operates in EU based on some legislation acts. One very important act is a Waste Framework Directive 2018/851. This directive sets the basic definitions and concepts related to problems connected with waste management-for example, definition of waste and definition of recycling. The directive also introduces the waste hierarchy [102]. The Landfill Directive (2018/850) is about prevention and reduction of the adverse effects of the landfill of waste on the surroundings. The Directive classifies the type of landfills and obligates Member States to minimize the amount of biodegradable waste in landfills [103]. Additionally, problems connected to waste to energy are mentioned in The European Green Deal (11 December 2020). It provides the EU strategy which aims towards the efficient usage of resources by moving towards a circular economy [104]. Another very important EU new document connected with waste to energy is the Circular Economy Action Plan (11 March 2020). This document gives specific strategies for how to move from a linear to a circular economy in the case of many materials such as, for example, textiles, food, plastics, construction, batteries, etc. [105].

\section{Methodology}

The main goal of this article is to describe the impact of technology entrepreneurship on strategic organizational effectiveness under the unexpected change COVID-19 in municipal waste to energy industry. Technology entrepreneurship is a strategic management category which theoretically should play a positive role in the context of organizational strategic development occurring in the context of an uncertain environment. The pandemic of COVID-19 is an example of unpredictable change, the nature of which is complex and its influence on organizational strategic development is multidimensional. The empirical research was conducted in the fourth quarter of 2020, while all statements were related to the situation of the surveyed company in the period from March to June 2020, i.e., the period of the first wave of the COVID-19 pandemic. This made it possible to capture the behavior of the surveyed enterprises during a surprising change. 
The survey statements were developed based on the analysis of previously published research on technology entrepreneurship and high-performance organizations. Technology entrepreneurship was measured in light of the configuration approach according to which various organizational phenomena consist of interconnected strategies and structures, and is not a situation in which all components can be easily understood in isolation. The most important strategies and structures which constitute the configuration of technology entrepreneurship which were measured in the questionnaire are the following [106-110]: (a) the strategy understood as long-term oriented organizational behavior is both the executive following the previously prepared plans and emergent according to occurring unpredictable changes (strategy both executed and emergent); (b) the organizational structure within which the technology entrepreneurship strategy is happening is flexible, team-based organization with distributed leadership (flexible structure and distributed leadership); (c) the organization has free resources at its disposal which allows the quick allocation of resources within the business model portfolio and according to unpredictable changes (unpredictable opportunity based resource allocation); (d) the central element of technology entrepreneurship in the form of the most advanced technologies used by the organization in its value-creation process (innovative technologies in value-creation process). Highperformance organizations were measured using a three-dimensional effectiveness model consisting of financial, development, and social organizational perspectives [61]. Each questionnaire statement was measured using a seven-point Likert scale with a choice of answers from 1 (strongly disagree) through 4 (don't know) to 7 (strongly agree). Particular statements were measured as the degree of compliance of the organization's state with a given statement, with performance statements assessed in relation to average industry performance. The research questionnaire is included in the Appendix A.

Waste management was chosen as a research area because, on the one hand, waste is a litmus test of the development processes of the entire economy, and on the other hand it is particularly exposed to viral infections such as COVID-19. The development measured by sales, financial measured by profitability of sales and employment performance statistics which describe the situation of whole waste management industry in Poland under COVID—19 are presented in Table 2.

Table 2. Economic indicators of waste management industry in Poland under first wave of the COVID-19 pandemic, in comparison with the entire industry; results after the first half of 2020 in light of the same date's previous three years.

\begin{tabular}{ccccccc}
\hline $\begin{array}{c}\text { End of 2017-2020 } \\
\text { Half Year/Economic } \\
\text { Parameter }\end{array}$ & $\begin{array}{c}\text { Sale } \\
\text { Industry [in } \\
\text { mln EUR] }\end{array}$ & $\begin{array}{c}\text { Sale Waste } \\
\text { Manag. [in } \\
\text { mln EUR] }\end{array}$ & $\begin{array}{c}\text { Profitability } \\
\text { of Sale } \\
\text { Industry [\%] }\end{array}$ & $\begin{array}{c}\text { Profitability of } \\
\text { Sale Waste } \\
\text { Management [\%] }\end{array}$ & $\begin{array}{c}\text { Employment } \\
\text { Industry [in } \\
\text { Thousand, Month } \\
\text { Average] }\end{array}$ & $\begin{array}{c}\text { Employment Waste } \\
\text { Management [in } \\
\text { Thousand, Month } \\
\text { Average] }\end{array}$ \\
\hline 2017 & 167,025 & 1570 & 6.6 & 4.8 & 2648 & 56 \\
2018 & $170,884 /$ & $1555 /$ & $6.6 /$ & $3.5 /$ & $2720 /$ & $59 /$ \\
& 2.3 & -0.95 & 0 & -0.27 & 0.03 & 0.05 \\
2019 & $184,663 /$ & $1823 /$ & $5.8 /$ & $6.9 /$ & 0.92 & 0.03 \\
2020 (after COVID-19 & 8 & 17.2 & -0.12 & 0.97 & $2773 /$ & $63 /$ \\
first wave) & $-162,945 /$ & $1999 /$ & $5.6 /$ & $10.9 /$ & $2660 /$ & 0.03 \\
\hline
\end{tabular}

Each data is supplemented with dynamics calculated as a degree of change in relation to the previous year.

Source: Statistics Poland database: stat.gov.pl (accessed on 31 June 2020), (according to NACE; industry: sections B, C, D, E; waste management industry: E38 - waste collection, treatment and disposal activities; materials recovery).

The statistics show the three-dimensional performance of the whole waste management industry after the first half of 2020, in comparison with the same periods in the past three years. Additionally, the same statistics are shown for the whole industry; in other words, the table includes main performance indicators of waste management in Poland under COVID-19 in time and industrial perspectives. From the information contained in the table, it can be concluded that the waste management industry has shown great resistance in relation to the unpredictable change in the form of the COVID-19 pandemic. This is clear in both time- and industrial-level comparisons, and taking into account all 
three performance indicators, but especially the development measured by sale level. Comparing all three waste management industry performance parameters in the same periods over the last three years (i.e., in the end of the June), it should be stated that they did not change. Surprisingly, the waste management industry developed at the same pace during the COVID-19 pandemic's first wave and during the three previous analogous periods when comparing the waste management industry with the entire Polish industry. Clear differences should be noted, especially with regard to the parameter of sales revenues. While sale showed stability for waste management industry, the entire Polish industry clearly slowed down.

The surprisingly positive results of the research on the resilience of the whole waste management industry in COVID-19 conditions encouraged us to continue the investigation in the form of a technology entrepreneurship explorative study of a small sample of the most effective enterprises. It was decided to focus on a deliberately selected sample of Polish companies producing alternative fuel based on waste Refused Derived Fuel (RDF). These enterprises are located in the center of the waste to energy industry, between storing and processing enterprises, which is part of the whole waste management branch. The high development potential of the waste to energy industry in Poland is shown in the below table (see Table 3); compared with recycling and landfilling, energy recovery in Poland is especially underestimated.

Table 3. The place of waste to energy in the whole Polish and EU waste management industries.

\begin{tabular}{|c|c|c|c|c|c|c|c|c|c|}
\hline \multirow{2}{*}{\multicolumn{2}{|c|}{ Years/Quantity }} & \multicolumn{2}{|c|}{ Waste Management } & \multicolumn{2}{|c|}{$\begin{array}{l}\text { Recovery-Energy } \\
\text { Recovery (R1) }\end{array}$} & \multicolumn{2}{|c|}{ Recovery-Recycling } & \multicolumn{2}{|c|}{$\begin{array}{l}\text { Disposal-Landfilling } \\
\text { (D1, D5, D12) }\end{array}$} \\
\hline & & $\begin{array}{c}\text { EU-27 } \\
\text { Countries }\end{array}$ & Poland & $\begin{array}{c}\text { EU-27 } \\
\text { Countries }\end{array}$ & Poland & $\begin{array}{c}\text { EU-27 } \\
\text { Countries }\end{array}$ & Poland & $\begin{array}{c}\text { EU-27 } \\
\text { Countries }\end{array}$ & Poland \\
\hline \multirow{2}{*}{2016} & $\mathrm{kgs} / \mathrm{cap}$ & 1504 & 1797 & 264 & 151 & 840 & 1007 & 357 & 519 \\
\hline & $\%$ & 100 & 100 & 18 & 8 & 56 & 56 & 24 & 29 \\
\hline \multirow{2}{*}{2014} & $\mathrm{kgs} / \mathrm{cap}$ & 1533 & 2055 & 233 & 142 & 848 & 1238 & 389 & 542 \\
\hline & $\%$ & 100 & 100 & 15 & 7 & 55 & 60 & 25 & 26 \\
\hline \multirow{2}{*}{2012} & $\mathrm{kgs} / \mathrm{cap}$ & 1510 & 1780 & 217 & 91 & 817 & 983 & 402 & 511 \\
\hline & $\%$ & 100 & 100 & 14 & 5 & 54 & 55 & 27 & 29 \\
\hline \multirow{2}{*}{2010} & $\mathrm{kgs} / \mathrm{cap}$ & 1448 & 1704 & 184 & 102 & 776 & 989 & 393 & 471 \\
\hline & $\%$ & 100 & 100 & 13 & 6 & 54 & 58 & 27 & 28 \\
\hline
\end{tabular}

Rows: years/kilograms per capita and percentage; columns: waste management operations/EU and Poland

Source: Eurostat, https: / /ec.europa.eu/eurostat/databrowser/view/ENV_WASOPER_custom_735567/default/table?lang=en. (accessed on 31 June 2020).

While recycling and landfilling indicators are similar in Poland and the EU (counted as an average of 27 countries) the energy recovery measures counted as a percentage of the whole waste management industry are at least two times lower. This shows that entrepreneurial development potential of the energy recovery sector is very strong in Poland. In addition, the waste to energy industry is based on incineration technologies which especially predispose them in the context of viral infections such as COVID-19. Because of regulatory and technological reasons, investments in energy recovery plants (R1) are very specific and decisions about location and the size of a waste to energy facility should also consider such factors as the gate fee. In other words, the investment algorithm in this case should be complex, e.g., taking into account that efficiency of R1 requires high utilization factor while the minimization of gate fee requires high $\mathrm{R} 1$ and high metals recovery (99). Similar to investment decisions, the development paths of individual plants and the whole waste to energy industry are multidimensional and go far beyond the free market conditions. On the one hand, scientific research shows the lack of impact of Purchase Power Priority (PPP) on the development of this industry, and, on the other hand, they condition this development with such determinants as the type of plant ownership, waste mobility or decentralization $(100,101)$. The very specific characteristics of the waste to energy industry were the stimulus to research the meaning 
of technology entrepreneurship as a conventional uncertainty management tool [111-113] in the circumstances of unpredictable change, such as COVID-19.

The analysis of the structure of the Polish WTE industry in the end of 2016 in the part of RDF producers and RDF processors is presented in Table 4. The total level of the market, market shares of the four biggest players, the market concentration ratio (105), minimum efficient scale (128) and economies of scale (130) are included in this table. The market concentration ration is defined as the accumulated percentage of market share of the four largest firms in the industry. Minimum efficient scale is formulated as the average firm size of the largest firms accounting for half of the industry output. The economies of scale ratios are calculated by dividing the minimum efficient scale by the market's total output.

Table 4. Structural analysis of WTE (RDF producers and processors) in Poland in 2016.

\begin{tabular}{|c|c|c|c|c|c|c|c|c|c|}
\hline $\mathrm{Nr}$ & $\begin{array}{l}\text { Name of } \\
\text { RDF } \\
\text { Producer }\end{array}$ & $\begin{array}{c}\text { Production } \\
\text { Size [Tons } \\
\text { per Year] }\end{array}$ & $\begin{array}{c}\text { Market } \\
\text { Share [\%] }\end{array}$ & $\begin{array}{c}\text { Cum. } \\
\text { MARKET } \\
\text { Share [\%] }\end{array}$ & $\mathrm{Nr}$ & $\begin{array}{l}\text { Namesof } \\
\text { RDF R1 } \\
\text { Processor }\end{array}$ & $\begin{array}{c}\text { R1 Processing } \\
\text { Size [Tons per } \\
\text { Year] }\end{array}$ & $\begin{array}{c}\text { Market } \\
\text { Share [\%] }\end{array}$ & $\begin{array}{c}\text { Cum. } \\
\text { Market } \\
\text { Share [\%] }\end{array}$ \\
\hline 1 & $\begin{array}{l}\text { NOVAGO } \\
\text { Ltd. }\end{array}$ & $194,932.73$ & 7.47 & 7.47 & 1 & $\begin{array}{l}\text { GÓRAŻDŻE } \\
\text { CEMENT } \\
\text { JSC }\end{array}$ & $266,020.10$ & 27.58 & 27.58 \\
\hline 2 & $\begin{array}{c}\text { PPHU } \\
\text { LEKARO } \\
\text { Jolanta } \\
\text { Zagórska }\end{array}$ & $186,730.30$ & 7.16 & 14.63 & 2 & $\begin{array}{c}\text { Grupa } \\
\text { Ożarów JSC }\end{array}$ & $181,726.26$ & 18.84 & 46.41 \\
\hline 3 & $\begin{array}{l}\text { MPO m.st. } \\
\text { Warszawie } \\
\text { Ltd. }\end{array}$ & $150,193.65$ & 5.76 & 20.39 & 3 & $\begin{array}{l}\text { LAFARGE } \\
\text { CEMENT } \\
\text { JSC }\end{array}$ & $146,566.31$ & 15.19 & 61.61 \\
\hline \multirow[t]{5}{*}{4} & $\begin{array}{l}\text { NOVAGO } \\
\text { ŻNIN Ltd. }\end{array}$ & $94,110.93$ & 3.61 & 23.99 & 4 & $\begin{array}{l}\text { Dyckerhoff } \\
\text { Polska Ltd. }\end{array}$ & $123,008.00$ & 12.75 & 74.36 \\
\hline & $\begin{array}{l}\text { Total } \\
\text { production }\end{array}$ & $2,608,958$ & & & & $\begin{array}{c}\text { Total } \\
\text { processing }\end{array}$ & 964,702 & & \\
\hline & $\begin{array}{c}\text { Concentration } \\
\text { ratio }\end{array}$ & 0.24 & & & & $\begin{array}{c}\text { Concentration } \\
\text { ratio }\end{array}$ & 0.47 & & \\
\hline & $\begin{array}{l}\text { Minimum } \\
\text { efficient scale }\end{array}$ & $87,076.26$ & & & & $\begin{array}{l}\text { Minimum } \\
\text { efficient scale }\end{array}$ & $198,104.22$ & & \\
\hline & $\begin{array}{l}\text { Economies of } \\
\text { scale }\end{array}$ & 0.03 & & & & $\begin{array}{l}\text { Economies of } \\
\text { scale }\end{array}$ & 0.21 & & \\
\hline
\end{tabular}

Source: website database on wastes, https://ibdo.pl/rynek-paliw-alternatywnych-20162017/ (accessed on 31 June 2020). The longer list of 15 the biggest RDF producers and processors in Poland in 2016 is included in the Appendix B.

The structural analysis of RDF producers shows that this sector in Poland is an industry with medium concentration and a significant number of firms. The measures of minimum efficient scale and economies of scale are quite low. A different situation is seen in the RDF $\mathrm{R} 1$ processors sector, as this industry in Poland is highly concentrated with few companies, mainly from the cement industry. The measures of minimum efficient scale and economies of scale are high, creating strong entry barriers. Comparing the economic parameters of RDF producers and processors presented in the above table, one can easily see the definite advantage of supply over demand of RDF on the Polish market. The bargaining power of the recipients in relation to RDF suppliers is overwhelming; additionally, low barriers to entry into the RDF producers sector create the possibility for processors to build their own RDF production plants. This results in increasing fees for RDF adoption and further, increasing profitability of RDF processing plants for energy. In Poland, a network of municipal plants transforming RDF into energy is currently being projected. Mostly, due to the high importance for local communities, high transport costs and large-scale investments, these are initiatives in the area of local public-private partnerships. Local, public-private RDF processing plants for energy should balance the current advantage of supply over demand in the RDF market in Poland and reduce the currently very strong competitive position of cement plants [114]. 
In the above-described industrial structure circumstances, a very interesting research question emerged about the technology entrepreneurship as an important success driver of RDF producers. The research question formulated on this phase of research was: what are the characteristic configurations of technology entrepreneurship in the case of highperforming RDF producers within the COVID-19 pandemic in Poland? The surveyed enterprises were manufacturers of RDF which represent an intermediary element of the Polish waste to energy industry (see Figure 1 below).

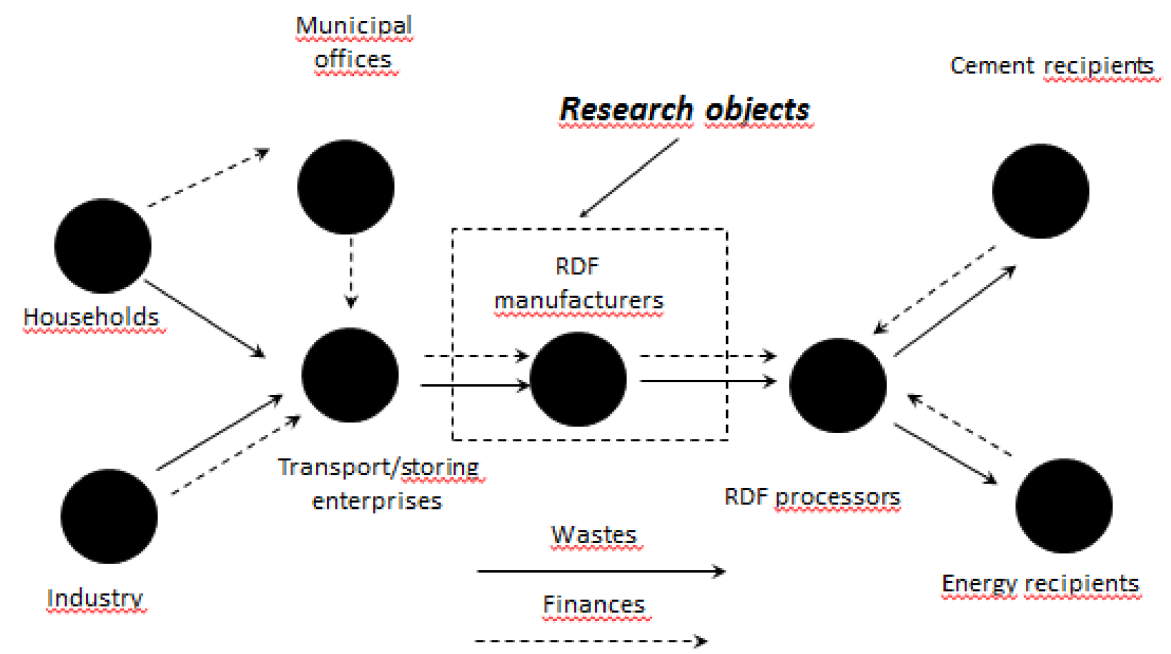

Figure 1. The case study research objects.

Exactly 25 enterprises represented by respondents who were members of management teams took part in the Computer Aided Telephone Interview (CATI) conducted in fourth quarter of 2020. The respondents were the members of top management of chosen enterprises. Ten enterprises were qualified for further research as high-performing RDF manufacturers (In Poland, the 15 biggest RDF producers cover 50\% of the whole RDF industry production, so only small sample research $(n<50)$ is possible). These were the respondents who declared at least one of three performance indicators more than the average in the industry. To analyze technology entrepreneurship as the driver of the high performance of RDF producers, the Fuzzy set Comparative Qualititave Method (FsQCA) was used. FsQCA is a methodology for obtaining linguistic summarizations from data that are associated with cases. It was developed by the social scientist Prof. Charles C. Ragin. FsQCA seeks to establish logical connections between combinations of causal conditions and an outcome, the result being rules that describe how combinations of causal conditions would cause the desired outcome. As such, each rule is a possible path from the causal conditions to the outcome. The rules are connected by the word OR to the output. In this article, in accordance with research question "what are the characteristic configurations of technology entrepreneurship in the case of high-performing RDF producers within the COVID-19 pandemic in Poland?", the combinations of causal conditions are configurations of technology entrepreneurship and an outcome is high-performance organization in the time of COVID-19. The general research idea with the use of the FsQCA method is presented below (see Figure 2).

The FsQCA method is especially dedicated to entrepreneurship research because of its configurative nature with asymmetries and multiple pathways [115]. As noted previously, technology entrepreneurship as a casual factor was measured using five survey statements regarding strategic executive and emergent behaviors, flexible structures and distributive leadership, allocation of resources within the business model portfolio and using the most advanced technologies in value creation process. High-performance organization as an outcome factor was measured using a three-dimensional performance scale consisting of development, financial and social effectiveness. The contextual dimension of the conceptual research model is the waste to energy industry in Poland in the COVID-19 pandemic. 


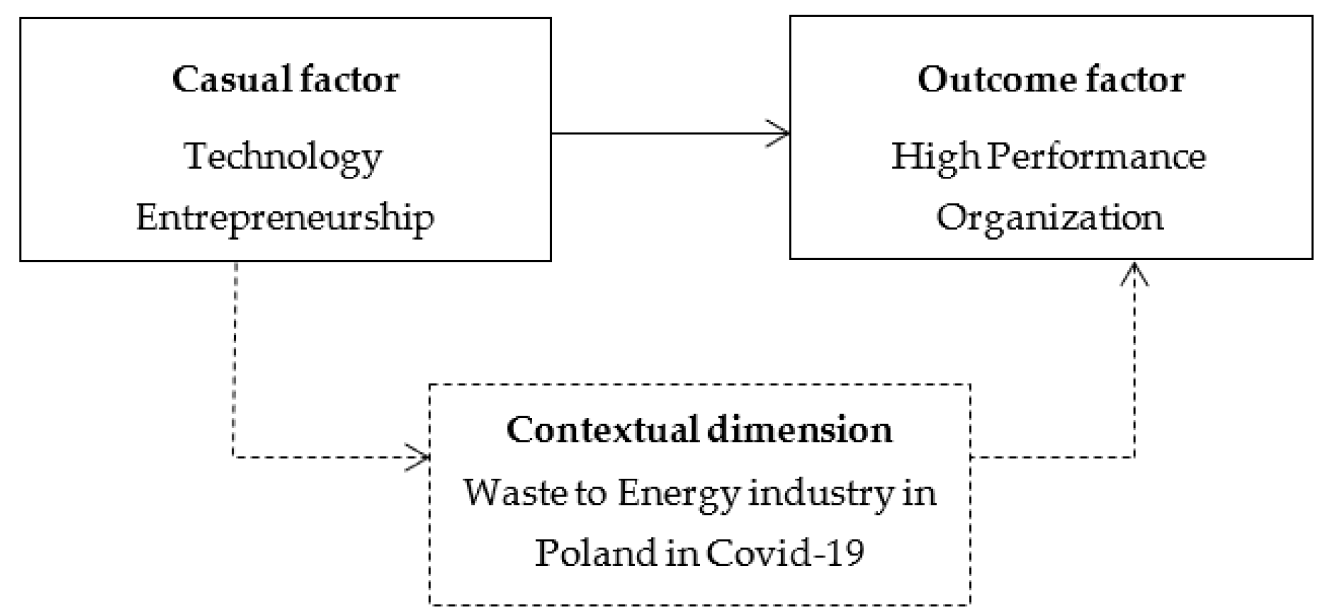

Figure 2. The conceptual research model.

\section{Results}

The main data analytic methodology was FsQCA. Fuzzy sets method was the base analytic logic, according to which fuzzy set $A$ in the certain space of considerations $X$ was defined as a set of the following pairs:

$$
A=\{(\mu \mathrm{A}(\mathrm{x}), \mathrm{x}): \mathrm{x} \in \mathrm{X}, \mu \mathrm{A}(\mathrm{x}): X \rightarrow[0,1]\}
$$

According to the conceptual research model (see Figure 2.) two main fuzzy sets were analyzed, i.e., a fuzzy set of enterprises characterized by different technology entrepreneurship features (in other words casual factors fuzzy sets) and a fuzzy set of high-performance organizations (in other words, the outcome factor fuzzy set). Considerations $X$ is the whole sample of researched enterprises and consideration $\mathrm{x}$ is the particular ith enterprise as the part of $X$. Membership function $\mu \mathrm{A}$ has two sub-functions:

- $\quad \mu_{C j}(i)$ - function of membership of the ith company to the set of enterprises with particular feature describing their technology entrepreneurship Cj (i.e., casual factor); - $\quad \mu_{\mathrm{E}}$ (i) - function of membership of the ith enterprise to the set of high-performance organization E (i.e., outcome factor).

In order to transform the 7-point Likert interval scale into fuzzy sets, the standard calibration procedure was used. According to this procedure, both measured variables (i.e., casual factor in the form of technology entrepreneurship and outcome factor as highperformance organization) were calibrated from the 7-point Likert scale to function of membership using the threshold for full membership (7-strongly agree), the threshold for full nonmembership (1-strongly disagree), and the cross-over point (5-I don't know).

Afterwards, on the basis of the functions $\mu_{\mathrm{E}}(\mathrm{i})$ and $\mu_{\mathrm{Cj}}(\mathrm{i})$, based on the logic of fuzzy sets and Bool's algebra, the impact of belonging to particular sets $C_{j}$ and to the set $E$ was analyzed. These analyzes can be formalized in the following form:

$$
\mathrm{Y} \rightarrow \mathrm{F}\left(\mathrm{x}_{1}, \mathrm{x}_{2}, \ldots\right)
$$

where: $Y$ means that a company belongs to the set of high-performance organizations, and $x_{j}$ means that a company belongs to the set of companies with the $j$-th feature (however, instead of $x$, its negation may occur). F means the logic formula which is the sum of products of logic simple sentences (each of which expresses the belonging of a company to one set $\mathrm{C}_{\mathrm{j}}$ ).

The above-described FsQCA procedure was carried out with the use of fsQCA 3.0 Windows software. Table 5 shows the calibration cutoffs and descriptive statistics of the research sample. 
Table 5. Sample Statistics and Calibration Parameters for fsQCA.

\begin{tabular}{|c|c|c|c|c|c|c|c|c|}
\hline & Mean & Std. Dev. & Min & $\operatorname{Max}$ & Med & Fully in & Max. Amb & Fully out \\
\hline $\begin{array}{c}\text { Outcome variable: } \\
\text { V0: organizational effectiveness }\end{array}$ & 4.4 & 1.070 & 3 & 7 & 5 & 7 & 4 & 1 \\
\hline $\begin{array}{l}\text { Casual variables: } \\
\text { V1: strategy both executed and emergent }\end{array}$ & 5.8 & 1.033 & 5 & 7 & 5 & 7 & 4 & 1 \\
\hline V2: flexible structure and distributed leadership & 4.3 & 1.636 & 1 & 7 & 5 & 7 & 4 & 1 \\
\hline V3: opportunity based resource allocation & 5.5 & 1.08 & 4 & 7 & 5 & 7 & 4 & 1 \\
\hline V4: innovative technologies in value creation process & 4.7 & 1.567 & 2 & 7 & 5 & 7 & 4 & 1 \\
\hline
\end{tabular}

Source: own study with use of excel.

The Table 6 includes the models of technology entrepreneurship configurations in the high-performing enterprises and RDF producers in the waste management industry in Poland under the conditions of the first wave of COVID 19 (i.e., in the period from March to June 2020). According to FsQCA methodology, consistency and coverage are two essential indexes for data synthesis. Consistency measures the degree to which solution terms and the solution as a whole are subsets of the outcome. It assesses the degree to which the combination of casual variables in the form of solution consistently produces the outcome variable. Coverage measures how much of the outcome is explained by each solution term and by the solution as a whole. In other words, it indicates the proportion of the sample's cases that reflects the solution. Raw coverage measures the proportion of memberships in the outcome explained by each term of the solution. Unique coverage measures the proportion of memberships in the outcome explained solely by each individual solution term. Consistency threshold indicates the acceptable level of dissimilarity between the conditions and the outcome for the cases represented by a particular configuration. Coverage threshold is to exclude solutions that are empirically trivial. In the literature there is a common practice that minimal consistency should be set at 0,8 and the coverage should be greater than $0.2[116,117]$. (The formalizations of consistency and coverage calculations are the following: Consistency $=\sum\left(\mathrm{min}\left(\mu_{\mathrm{Cj}}\right.\right.$, $\left.\left.\mu_{\mathrm{E}}\right)\right) / \sum\left(\mu_{\mathrm{Cj}_{\mathrm{j}}}\right)$; Coverage $\left.=\sum\left(\min \left(\mu_{\mathrm{Cj}_{\mathrm{j}}}, \mu_{\mathrm{E}}\right)\right) / \sum\left(\mu_{\mathrm{E}}\right)\right)$.

Table 6. Technology entrepreneurship configurations of high-performing RDF producers in Poland.

\begin{tabular}{ccc}
\hline Model & Row Coverege & Unique Coverage \\
\hline Construct: $\mathrm{f} V \mathrm{~V} 0=\mathrm{f} \_(\mathrm{V} 1, \mathrm{~V} 2, \mathrm{~V} 3, \mathrm{~V} 4)$ & & 0.09 \\
$\mathrm{M} 1: \mathrm{V} 1 * \sim \mathrm{V} 2 * \mathrm{~V} 3$ & 0.59 & 0.38 \\
$\mathrm{M} 2: \mathrm{V} 1^{*} \mathrm{~V} 3^{*} \mathrm{~V} 4$ & 0.88 & 0.88 \\
Solution coverage: $0.97 ;$ solution & & \\
consistency: 0.89 & & \\
\hline
\end{tabular}

Explanations: $\mathrm{f} \_\mathrm{V} 0$ is an outcome factor consisted of one variable (i.e., organizational effectiveness); $\mathrm{M} 1$ and M2 are technology entrepreneurship configurations or models for high effectiveness organizations; M1 stands for hig- performance technology entrepreneurship model 1 (solution term1); M2 stands for high-performance technology entrepreneurship model 2 (solution term2). The sum of solution term 1 and solution term 2 is the whole solution.

Source: own study with use of fs/QCA 3.0 Windows Software on the base of complex solution (the raw output generated by the software is included as Appendix C).

Two alternative models of technology entrepreneurship of high-performing RDF producers in Poland were identified with solution coverage of 0.97 and solution consistency 0.89 , as evident in the Table 3 . Both configurations are based on strategic behaviors based on both execution and emergence and opportunity-based resource allocation. They differ taking into account flexible structure and distributed leadership and using innovative technologies in value creation process.

The first model is based on the strategic behavior of the organization as both the implementation of strategic plans and current opportunism, rigid organizational structures and a permanent leadership position, and flexible, opportunity based allocation of resources within a business models portfolio. This model does not take into account process innovations and is based on manufacturing technologies that are traditional in the industry. The second model, as with the previous one, is based on implementation and emergent strategic behaviors of the organization and flexible allocation of resources within the business 
model portfolio; however, unlike the previous model, it uses innovative manufacturing technologies. By synthesizing the obtained models of technological entrepreneurship in the RDF producers industry, it can be concluded that the strategic emergence and flexible allocation of resources, characteristic for organizational entrepreneurship, occur in the first model based on rigid organizational structures and around traditional manufacturing technologies, while in the second model around innovative RDF manufacturing technologies. Both configurations in an equal way lead to above-average performance in the RDF producers industry. Thus, two different main configurations of casual variables describing technology entrepreneurship concepts culminate in the high-performing RDF producer. The main difference between models is rooted in structures, leadership and using innovative technologies in the production process.

\section{Discussion and Conclusions}

Technology entrepreneurship as a strategic development process plays an especially important role in the context of unpredictable change management. Strategic organizational behaviors which are based only on strategy execution are insufficient in the uncertain environment and strategic emergency seems to be necessary. In turbulent times, such as in times of the COVID-19 pandemic, the strategic thinking in an organization is not easy. The problems with strategic thinking come from the fact that the future is unpredictable and represents unknown domains in terms of business evolution, disruption and technology. Additionally, technology entrepreneurship is not easy in those times [35-37].

In this paper, we tried to find out the impact of technology entrepreneurship on strategic organizational effectiveness under the unexpected change of COVID-19 in the municipal waste to energy industry. We tried to find out what combination of organization characteristics in the field of technological entrepreneurship leads to being a high-performing producer in the waste to energy sector. There were not analyses about such a topic in the literature, but we can find many papers about the impact of a pandemic on the various types of business [118]. It is interesting that in some branches the pandemic effect was the decrease of the production amount and problems with functioning of the organizations [1,119-122]. In others the effect was not so big, or even in some cases authors observed a positive effect of the pandemic on organizations [123-125].

Flexible organizational structures and distributed leadership occurring around the most innovative technologies are key organizational capabilities in uncertain times [126,127]. In other words, technology entrepreneurship understood as emergent strategic behaviors based on flexible structures and distributed leadership around the core of the most innovative technologies is a key organizational capability which allows achieving highperformance strategic measures. The COVID-19 pandemic is an example of unpredictable change which affects the performance of the entire economy. Waste management, as an important part of the entire economic system, was chosen as a research area because on the one hand, waste is a litmus test of the development processes of the entire economy, and on the other hand it is particularly exposed to viral infections such as COVID-19. The main purpose of the article was to describe the performance meaning of technology entrepreneurship in waste management industry in the context of unpredictable complex change such as the COVID-19 pandemic.

The overall conclusions can be divided in two parts, first regarding the influence of COVID-19 on the whole waste to energy industry in Poland and second regarding the most effective technology entrepreneurship configuration in the industry. Describing the influence of COVID-19 on the whole industry, surprisingly, the waste management industry in Poland developed at the same pace during the COVID-19 first wave pandemic and during the three previous years' analogous periods. Level of sales and employment in the entire waste management industry did not change under COVID-19, and what is especially interesting is that the level of profitability of sales even grew. It is an especially interesting conclusion that, in the context of the same sale, profitability of sale and employment indicators for the entire industry in Poland fell very noticeably (see Table 1). In our 
analysis, we observe that in waste to energy enterprises the pandemic has positive effects on organizations. It is interesting that the sales increased and also we can observe the increase of profitability of sales. The same was observed in the wastetoenergy branch in China by Zhou [6]. This suggests that the situation is not only specific for the researched organization in Poland, but could be typical for this branch. However, in many other branches we lead with different situations and the pandemic lead to decreases in production levels, and it was troublesome for organizations [118].

Additionally, in this branch the COIVID-19 pandemic has positive effects on innovativeness. For example, Sarkodie and Owusu have found that COVID-19 has a positive impact on the zero-waste approach in European Union countries. This approach encompasses the conservation of all needed resources by means of responsible consumption, production, recovery of products and reuse with no discharges to land, water or air that could treat the environment of humans [128,129]. Further, other authors think that the troublesome situation can be a chance for progress in this industry.

It can therefore be concluded that the industry was a kind of economic oasis in the pandemic.

The second part of our research was performed using Qualitative Comparative Analysis (QCA) which is based on fuzzy set logic. Using QCA, we tried to identify patterns which lead organizations to achieve high-performance results. In our research, we have found that there are two possible patterns of high-performance companies in the waste to energy industry.

The two prevailing technology entrepreneurship configurations characteristic for high-performing waste to management industry enterprises are the following:

M1: traditional manufacturing technologies and hierarchical structures with a fixed leader position technology entrepreneurship model and

M2: an innovative manufacturing technologies technology entrepreneurship model.

Our models were identified using a configurational approach based on Ragin's conception [72,73,75-77]. We use the mentioned software to identify those two models based on empirical data. The models are not trivial and we can spot, in analyzing them, some differentials with typical, well-established conceptions.

The first model is used in traditional organizations. The model means that an organization can have good results and be included as a high-performance organization even if they are not very innovative. However, this is possible only in organizations with established market positions and flexible allocations of the organization's resources. We think this is an very interesting finding of the paper, because many other authors think that the high-performance organizations should be very innovative and flexible [54,56,57,130,131]. We think that is not always true. Additionally, De Wall's concept about high-performing organizations [61] concentrated on autonomy and continuous improvement. Sometimes it is needed, and those traits will be important in our second identified model, but this first model is not accordance with it. In this particular situation some organizations can be high-performance organizations without a high level of autonomy.

In some situations, big organizations with hierarchical structures may function well on the market and may have a potential to grow. This type of organization uses its good market position and tries to defend it using a rather passive strategy. However, in an industry which is not very innovative this could be a successful strategy.

The second strategy that leads to a high-performance organization position is based on innovative approaches and entrepreneurship. It is used in the case of organizations without an established market position which can be increased using new, innovative solutions. This solution is more typical for high-performance organizations and many international researchers have found that innovativeness is a very important part of high-performing enterprise configurations [51-53,56,57]. This model is in accordance with others authors' main findings $[38,39,54-59]$.

Both models are based on emergent strategic behaviors which complement the strategy execution and flexible allocation of resources within the business model portfolio. The 
difference between them, beyond the technology innovativeness, is the type of organizational structure and leadership. The first model leverages the traditional organizational structures, and the second seems to be based on more flexible forms.

The main contribution of our paper is the finding that traditional organization can also achieve good results in the waste to energy market if they use an appropriate strategy. Those types of organizations can also be high-performing organizations and have a good market position and good results of their activity.

Our main finding is that in the waste to energy industry, there are two independent paths to achieve being a high-performing enterprise. One path is useful for bigger, established, on-the-market organizations and the second one is useful for new organizations trying to find their place on market. Those two strategies should not be mixed and each one is adjusted to a particular type of organization. We think this finding is important for waste to energy organizations, not only from Poland but also from other countries. They, based on their market position, should choose an appropriate strategy to achieve a good position and to be a type of high-performing organization.

The main novelty in this study connects with implementing technological entrepreneurship conceptions and the QCA method to the waste to energy market. The implementation of new circular economy solutions for waste to energy needs a sufficient level of technological entrepreneurship. It is interesting from an economics and management point of view to know what configuration of entrepreneurship traits lead to an organization's good functioning and achieving a high efficiency in the waste to energy market. To do this, we used the very prospecting and mathematically advanced method of QCA based on fuzzy logic. The use of this method allowed us to identify configurations of entrepreneurship characteristics which are not possible to identify in another way. We think that the usage of the QCA method in this case is interesting because we did not find a paper about technological entrepreneurship in the waste to energy market based on the QCA method. In addition, we think the identification of two types of configuration of technological entrepreneurship trends means that the identification of two different models leading to high-performing organizations can be a contribution to the field of the management of the waste to energy market. Those two models are valuable from a scientific and also practical perspective, because organizations on this market can use them to achieve high performance.

The solution can be useful for an organization in the process of transformation towards a circular economy. When an organization knows what configurations of traits leads to high performance, an organization can try to use this knowledge. We think our findings can be very useful especially for stakeholders of organizations. The two types of technology entrepreneurship configurations are useful because when organizations implement a waste to energy strategy, they can use one of them to achieve good results. When organizations have good results, we can include it as a high achieving organization as it leads to the fulfillment of customers' and employer's needs. These organizations have a positive impact on the natural environment and also generate places of work in local communities. This is important and positive from a local government and economical organization point of view. This study has some limitations. The first limitation is that the research was done on a small populace of organizations from one country. However, we should mention that the waste to energy market in Poland is not big and researched organizations are about $40 \%$ of Polish waste to energy industry organizations. Further, we used the fs/QCS method, which is appropriate for analysis of small groups of data [116,117]. The second limitation is connected with operalization of variables. Our operalization was only one possible solution, but we based it on extensive literature analysis $[38,39,56,57,106-110,132-140]$. Because of the limitations of our study we cannot generalize all results on the whole waste to energy industry. We analyzed only high-performance organizations and, in the case of our identified configurations, they can be used only for those parts of waste to energy organizations.

Future research can concentrate on using this method in other types of organizations and other industries. It is worth investigating if the same two models of how to achieve 
a level of high-performing organization by technological entrepreneurship are present in other industries or if in each industry we can find different types of models.

Author Contributions: The main activities of the team of authors can be described as follows: Conceptualization, P.K.; methodology, P.K., R.W.; software, P.K.; validation, P.K., R.W.; formal analysis, P.K., R.W.; investigation, P.K.; resources, P.K., R.W.; data curation P.K., R.W.; writingoriginal draft preparation, P.K., R.W.; writing—review and editing, P.K., R.W.; visualization, P.K., R.W.; supervision, P.K., R.W.; funding acquisition, P.K., R.W. All authors have read and agreed to the published version of the manuscript.

Funding: The analysis in this publication has been made in the course of the internal research project of Silesian University of Technology project 13/010/BK_21/0057.

Institutional Review Board Statement: Not applicable.

Informed Consent Statement: Not applicable.

Data Availability Statement: Data is contained within the article.

Conflicts of Interest: The authors declare no conflict of interest.

\section{Appendix A. Technology Entrepreneurship Questionnaire}

\begin{tabular}{|c|c|c|c|c|c|c|c|}
\hline 1. Name, legal form and www of the company & & & & $\ldots \ldots$. & & & \\
\hline 2. Employment in the end of 2019 & & & & $\ldots \ldots \ldots$ & & & \\
\hline 3. Revenues in the end of 2019 & & & & $\ldots \ldots \ldots$ & & & \\
\hline $\begin{array}{l}\text { 4. After the first half of } 2020 \text { the company } \\
\text { gained the return on sale higher than avarege } \\
\text { in the RDF producers sector in Poland }\end{array}$ & $\begin{array}{l}1 \text { (strongly } \\
\text { disagree) }\end{array}$ & 2 (no) & $\begin{array}{c}3 \text { (rather } \\
\text { no) }\end{array}$ & $\begin{array}{l}4 \text { (I don't } \\
\text { know) }\end{array}$ & $\begin{array}{c}5 \text { (rather } \\
\text { yes) }\end{array}$ & 6 (yes) & $\begin{array}{c}7 \text { (strongly } \\
\text { agree) }\end{array}$ \\
\hline $\begin{array}{l}\text { 5. After the first half of } 2020 \text { the company } \\
\text { gained the level of sale increase higher than } \\
\text { avarege in the RDF producers sector in Poland }\end{array}$ & $\begin{array}{c}1 \text { (strongly } \\
\text { disagree) }\end{array}$ & 2 (no) & $\begin{array}{c}3 \text { (rather } \\
\text { no) }\end{array}$ & $\begin{array}{l}4 \text { (I don't } \\
\text { know) }\end{array}$ & $\begin{array}{c}5 \text { (rather } \\
\text { yes) }\end{array}$ & 6 (yes) & $\begin{array}{c}7 \text { (strongly } \\
\text { agree) }\end{array}$ \\
\hline $\begin{array}{l}\text { 6. Within the first half of } 2020 \text { the company } \\
\text { employees level of engagement in its } \\
\text { processes were greater than avarege in the } \\
\text { RDF producers sector in Poland }\end{array}$ & $\begin{array}{l}1 \text { (strongly } \\
\text { disagree) }\end{array}$ & 2 (no) & $\begin{array}{c}3 \text { (rather } \\
\text { no) }\end{array}$ & $\begin{array}{l}4 \text { (I don't } \\
\text { know) }\end{array}$ & $\begin{array}{c}5 \text { (rather } \\
\text { yes) }\end{array}$ & 6 (yes) & $\begin{array}{c}7 \text { (strongly } \\
\text { agree) }\end{array}$ \\
\hline $\begin{array}{l}\text { 7. The strategy understood as long term } \\
\text { oriented organizational behavior is both the } \\
\text { executive following the previously prepared } \\
\text { plans and emergent according to occurring } \\
\text { unpredictable changes (strategy both executed } \\
\text { and emergent) }\end{array}$ & $\begin{array}{c}1 \text { (strongly } \\
\text { disagree) }\end{array}$ & 2 (no) & $\begin{array}{c}3 \text { (rather } \\
\text { no) }\end{array}$ & $\begin{array}{l}4 \text { (I don't } \\
\text { know) }\end{array}$ & $\begin{array}{c}5 \text { (rather } \\
\text { yes) }\end{array}$ & 6 (yes) & $\begin{array}{c}7 \text { (strongly } \\
\text { agree) }\end{array}$ \\
\hline $\begin{array}{l}\text { 8. The organizational structure within which } \\
\text { the technology entrepreneurship strategy is } \\
\text { happening is flexible, team based organization } \\
\text { with distributed leadership (flexible structure } \\
\text { and distributed leadership) }\end{array}$ & $\begin{array}{l}1 \text { (strongly } \\
\text { disagree) }\end{array}$ & 2 (no) & $\begin{array}{c}3 \text { (rather } \\
\text { no) }\end{array}$ & $\begin{array}{l}4 \text { (I don't } \\
\text { know) }\end{array}$ & $\begin{array}{c}5 \text { (rather } \\
\text { yes) }\end{array}$ & 6 (yes) & $\begin{array}{c}7 \text { (strongly } \\
\text { agree) }\end{array}$ \\
\hline $\begin{array}{l}\text { 9. The organization has free resources at } \\
\text { disposal which allows the quick allocation of } \\
\text { resources within the business model portfolio } \\
\text { and according to the unpredictable changes } \\
\text { (unpredictable opportunity based resource } \\
\text { allocation) }\end{array}$ & $\begin{array}{c}1 \text { (strongly } \\
\text { disagree) }\end{array}$ & 2 (no) & $\begin{array}{c}3 \text { (rather } \\
\text { no) }\end{array}$ & $\begin{array}{l}4 \text { (I don't } \\
\text { know) }\end{array}$ & $\begin{array}{c}5 \text { (rather } \\
\text { yes) }\end{array}$ & 6 (yes) & $\begin{array}{c}7 \text { (strongly } \\
\text { agree) }\end{array}$ \\
\hline $\begin{array}{l}\text { 10. The central element of technology } \\
\text { entrepreneurship in the form of most } \\
\text { advanced technologies used by the } \\
\text { organization in value creation process } \\
\text { (innovative technologies in value creation } \\
\text { process) }\end{array}$ & $\begin{array}{c}1 \text { (strongly } \\
\text { disagree) }\end{array}$ & 2 (no) & $\begin{array}{c}3 \text { (rather } \\
\text { no) }\end{array}$ & $\begin{array}{l}4 \text { (I don't } \\
\text { know) }\end{array}$ & $\begin{array}{c}5 \text { (rather } \\
\text { yes) }\end{array}$ & 6 (yes) & $\begin{array}{c}7 \text { (strongly } \\
\text { agree) }\end{array}$ \\
\hline
\end{tabular}


Appendix B. The Market Shares of 15 the Biggest RDF Producers and Processors in Poland in 2016

\begin{tabular}{|c|c|c|c|c|c|c|c|c|c|}
\hline $\mathrm{Nr}$ & $\begin{array}{l}\text { Names of RDF } \\
\text { Producers }\end{array}$ & $\begin{array}{c}\text { Production } \\
\text { Size [Tons } \\
\text { per Year] }\end{array}$ & $\begin{array}{c}\text { Market } \\
\text { Share } \\
{[\%]}\end{array}$ & $\begin{array}{c}\text { Cumulative } \\
\text { Market } \\
\text { Share [\%] }\end{array}$ & $\mathrm{Nr}$ & $\begin{array}{l}\text { Names of RDF R1 } \\
\text { Processors }\end{array}$ & $\begin{array}{l}\text { R1 Processing } \\
\text { Size [Tons per } \\
\text { Year] }\end{array}$ & $\begin{array}{c}\text { Market } \\
\text { Share } \\
{[\%]}\end{array}$ & $\begin{array}{c}\text { Cumulative } \\
\text { Market } \\
\text { Share [\%] }\end{array}$ \\
\hline 1 & NOVAGO Sp. z o.o. & $194,932.7$ & 7.47 & 7.47 & 1 & $\begin{array}{l}\text { GÓRAŻDŻE CEMENT } \\
\text { S.A. }\end{array}$ & 266,020 & 27.58 & 27.58 \\
\hline 2 & $\begin{array}{c}\text { PPHU LEKARO Jolanta } \\
\text { Zagórska }\end{array}$ & $186,730.3$ & 7.16 & 14.63 & 2 & Grupa Ożarów S.A. & 181,726 & 18.84 & 46.41 \\
\hline 3 & $\begin{array}{l}\text { MPO m.st. Warszawie } \\
\text { Sp. z o.o. }\end{array}$ & $150,193.7$ & 5.76 & 20.39 & 3 & $\begin{array}{l}\text { LAFARGE CEMENT } \\
\text { S.A. }\end{array}$ & 146,566 & 15.19 & 61.61 \\
\hline 4 & $\begin{array}{l}\text { NOVAGO ŻNIN Sp. z } \\
\text { o.o. }\end{array}$ & $94,110.93$ & 3.61 & 23.99 & 4 & $\begin{array}{c}\text { Dyckerhoff Polska Sp. z } \\
\text { o.o. }\end{array}$ & 123,008 & 12.75 & 74.36 \\
\hline 5 & $\begin{array}{l}\text { ZGOK Sp. z o.o. w } \\
\text { Olsztynie }\end{array}$ & $90,100.2$ & 3.45 & 27.45 & 5 & Lafarge Cement S.A. & $113,071.08$ & 11.72 & 86.08 \\
\hline 6 & $\begin{array}{l}\text { EKOPALIWA CHEEM } \\
\text { Sp. z o.o. }\end{array}$ & $88,538.17$ & 3.39 & 30.84 & 6 & CEMEX Polska Sp. z o.o. & $51,763.98$ & 5.37 & 91.44 \\
\hline 7 & PUK Empol Sp. z o.o. & 76,132 & 2.92 & 33.76 & 7 & $\begin{array}{c}\text { Cementownia ODRA } \\
\text { S.A. }\end{array}$ & $25,800.7$ & 2.67 & 94.12 \\
\hline 8 & EKO-MYŚL Sp. z o.o. & $65,878.4$ & 2.53 & 36.28 & 8 & STORA ENSO Sp z o.o. & $16,613.89$ & 1.72 & 95.84 \\
\hline 9 & NOVAGO Sp. z o.o. & $58,890.36$ & 2.26 & 38.54 & 9 & P.U.H.P. LECH Sp z o.o. & $13,489.68$ & 1.40 & 97.24 \\
\hline 10 & $\begin{array}{l}\text { ZUO CLEAN CITY Sp. } \\
\text { z o.o. }\end{array}$ & $53,934.58$ & 2.07 & 40.61 & 10 & Grupa OŻARÓW S.A. & $13,040.98$ & 1.35 & 98.59 \\
\hline 11 & KOM-EKO S.A. & 53,261 & 2.04 & 42.65 & 11 & $\begin{array}{c}\text { MPO Warszawa Sp. z } \\
\text { o.o. }\end{array}$ & $12,142.4$ & 1.26 & 99.85 \\
\hline 12 & BM Recykling Sp. z o.o. & 52,295 & 2.00 & 44.65 & 12 & $\begin{array}{c}\text { Elektrownia Połaniec } \\
\text { S.A. }\end{array}$ & 1118.1 & 0.12 & 99.96 \\
\hline 13 & STAROL Sp. z o.o. & $48,455.84$ & 1.86 & 46.51 & 13 & Mo-BRUK S.A. & 290.96 & 0.03 & 99.99 \\
\hline 14 & Partners Sp. z o.o. Sp. K. & $47,073.54$ & 1.80 & 48.32 & 14 & MZGOK Konin & 40 & 0.00 & \#\#\#\#\# \\
\hline \multirow[t]{3}{*}{15} & Mo-BRUK S.A. & $45,617.2$ & 1.75 & 50.06 & 15 & & & & \\
\hline & Sum: & $1,306,144$ & & & & Sum: & 964,692 & & \\
\hline & Total: & $2,608,958$ & & & & Total: & 964,702 & & \\
\hline
\end{tabular}

Source: website database on wastes, https:/ /ibdo.pl/rynek-paliw-alternatywnych-20162017 / (accessed on 31 June 2020).

Appendix C. Technology Entrepreneurship Configurations of High-Performing RDF Producers in Poland-Raw Output Generated by the fs/QCA 3.0 Windows Software

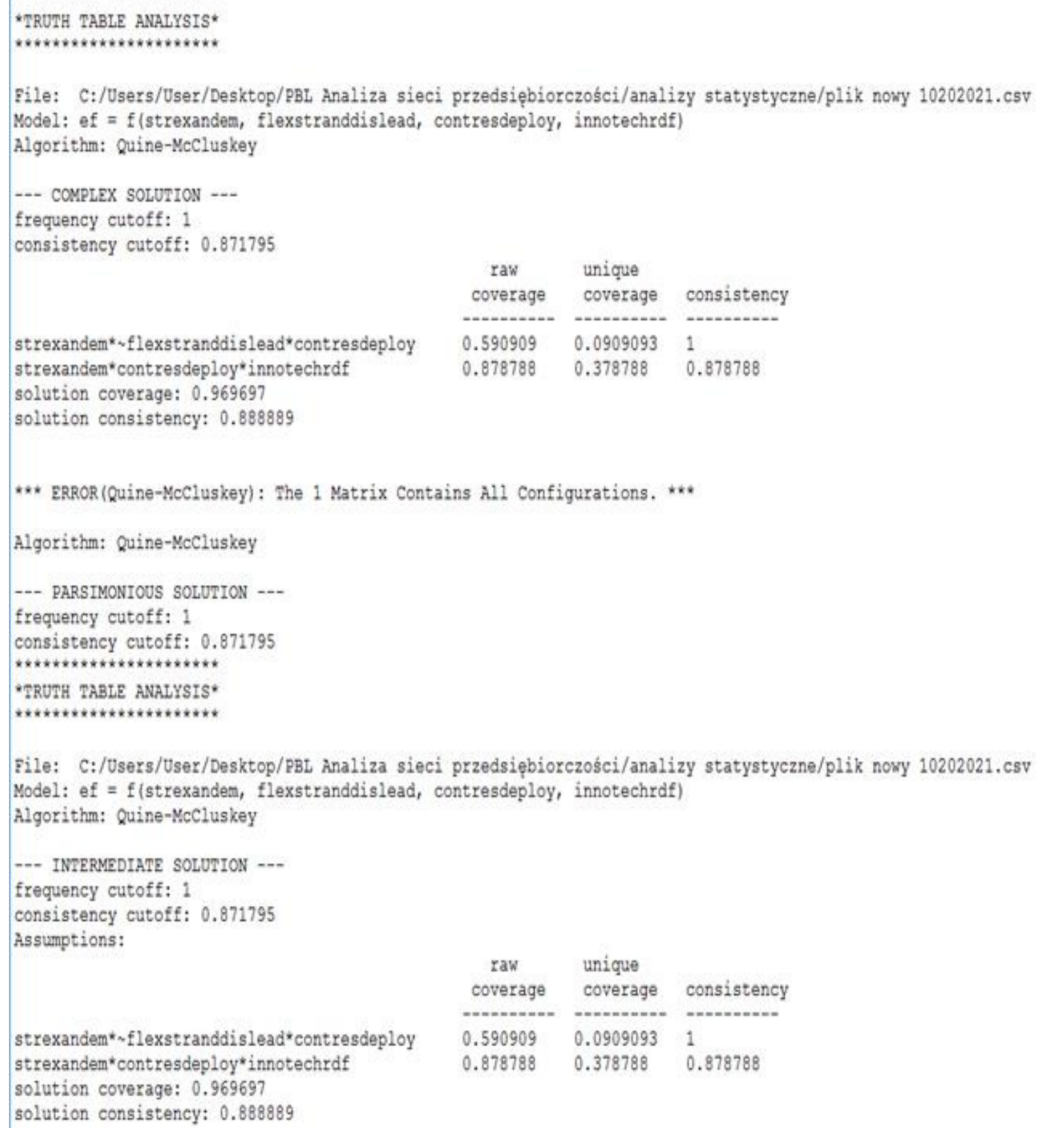




\section{References}

1. Gajdzik, B.; Wolniak, R. Influence of the COVID-19 crisis on steel production in Poland compared to the financial crisis of 2009 and to boom periods in the market. Resources 2021, 10, 4. [CrossRef]

2. Nandi, S.; Sarkis, J.; Hervani, A.A.; Helms, M.M. Redesigning Supply Chains using Blockchain-Enabled Circular Economy and COVID-19 Experiences. Sustain. Prod. Consumpt. 2021, 27, 10-22. [CrossRef]

3. Untaru, E.-N.; Han, H. Threat or opportunity? A case study of digital-enabled redesign of entrepreneurship education in the COVID-19 emergency. Technol. Forecast. Soc. Change 2021, 166, 120565.

4. Stoop, N.; Desbureaux, S.; Kaota, A.; Lunanga, E.; Verpoorten, M. Covid-19 vs. Ebola: Impact on households and small businesses in North Kivu, Democratic Republic of Congo. World Dev. 2021, 140, 105352. [CrossRef]

5. Dube, K.; Nhamo, G.; Chikodzi, D. COVID-19 pandemic and prospects for recovery of the global aviation industry. J. Air Transp. Manag. 2021, 92, 102022. [CrossRef]

6. Zhou, C.; Yang, G.; Ma, S.; Liu, Y.; Zhao, Z. The impact of the COVID-19 pandemic on waste-to-energy and waste-to-material industry in China. Renew. Sustain. Energy Rev. 2021, 139, 110693. [CrossRef]

7. Verma, C.; Alrefaee, S.H.; Quraishi, M.A.; Ebenso, E.E.; Hussain, C.M. Environmental, safety and economic risks of Covid-19 pandemic in petroleum industries: A prospective. J. Petrol. Sci. Eng. 2021, 198, 108161. [CrossRef]

8. Sarfraz, Z.; Sarfraz, A.; Iftikar, H.M.; Akhund, R. Is covid-19 pushing us to the fifth industrial revolution (Society 5.0)? Pak. J. Med. Sci. 2020, 37, 1-4.

9. Ratten, V. Coronavirus (Covid-19) and entrepreneurship: Cultural, lifestyle and societal changes. J. Entrepreneur. Emerg. Econ. 2020. [CrossRef]

10. Meahjohn, I.; Persad, P. The Impact of COVID-19 on Entrepreneurship Globally. J. Econ. Bus. 2020, 3, 1165-1173. [CrossRef]

11. Naudé, W. Entrepreneurial Recovery from COVID-19: Decentralization, Democratization, Demand, Distribution, and Demography; Maastricht School of Management and University of Leiden: Leiden, The Netherlands, 2020.

12. Bărbulescu, O.; Tecău, A.S.; Munteanu, D.; Constantin, C.P. Innovation of startups, the key to unlocking post-crisis sustainable growth in Romanian entrepreneurial ecosystem. Sustainability 2021, 13, 671. [CrossRef]

13. Tang, D.; Li, X. Thoughts on innovation and entrepreneurship mode reform of college students in the context of COVID-19. Int. J. Electr. Eng. Educ. 2021. [CrossRef]

14. Zahra, S.A. International entrepreneurship in the post Covid world. J. World Bus. 2021, 56, 101143. [CrossRef]

15. Korsgaard, S.; Hunt, R.A.; Townsend, D.M.; Ingstrup, M.B. COVID-19 and the importance of space in entrepreneurship research and policy. Int. Small Bus. J. Res. Entrepreneur. 2020, 38, 697-710. [CrossRef]

16. Syriopoulos, K. The impact of COVID-19 on entrepreneurship and SMEs. J. Int. Acad. Case Stud. 2020, $26,2-3$.

17. Shepherd, D.A. COVID 19 and Entrepreneurship: Time to Pivot? J. Manag. Stud. 2020, 57, 1750-1753. [CrossRef]

18. Mantaeva, E.I.; Goldenova, V.S.; Slobodchikova, I.V.; Avadaeva, I.V. The Role of Technological Entrepreneurship in the System of Regional Economy: Problems and Perspectives of Development. Lect. Notes Netw. Syst. 2021, 155, 1406-1412.

19. Korobov, S.A.; Moseyko, V.O.; Marusinina, E.Y.; Devyatkina, D.S. Foreign Practice of Application of Smart Technologies to Support Technological Entrepreneurship: Prospects for Application in Russia. Lect. Notes Netw. Syst. 2021, 155, 1642-1648.

20. Du, E.; Meng, J. Prediction and validation of the promoting effect of technological entrepreneurship on sustainable economic growth. Int. J. Sustain. Dev. Plan. 2020, 15, 1113-1118. [CrossRef]

21. Sun, C.; Li, C.; Zhang, J. Evaluation on Symbiotic Performance of Regional Technological Entrepreneurship Ecosystem. Lect. Notes Electr. Eng. 2020, 582, 401-411.

22. Linton, J.D.; Xu, W. Research on science and technological entrepreneurship education: What needs to happen next? J. Technol. Transf. 2020. [CrossRef]

23. Duval-Couetil, N.; Ladisch, M.; Yi, S. Addressing academic researcher priorities through science and technology entrepreneurship education. J. Technol. Transf. 2020. [CrossRef]

24. Gajdzik, B. Comprehensive classification of environmental aspects in a manufacturing enterprise. Metalurgija 2012, 51, 541-544.

25. Saniuk, S.; Grabowska, S.; Gajdzik, B. Social Expectations and Market Changes in the Context of Developing the Industry 4.0 Concept. Sustainability 2020, 12, 1362. [CrossRef]

26. Pacana, A.; Andrzej Gazda, A.; Bednárová, L. The impact of quality information on innovatory environment of the public administration. Int. J. Interdiscip. Theory Pract. ITPB 2014, 4, 25-26.

27. Pacana, A.; Ulewicz, R. Analysis of causes and effects of implementation of the quality management system complaint with ISO 9001. Pol. J. Manag. Stud. 2020, 21, 283-296.

28. Shvetsova, O.A.; Lee, J.H. Minimizing the Environmental Impact of Industrial Production: Evidence from South Korean Waste Treatment Investment Projects. Appl. Sci. 2020, 10, 3489. [CrossRef]

29. Ouyang, Y.; Cai Yanpeng Hongijang, G. Visualization and Analysis of Mapping Knowledge Domains for Food Waste Studies. Int. J. Environ. Res. Public Health 2021, 18, 5143. [CrossRef]

30. Waste to Energy in the Age of the Circular Economy. Best Practice Handbook; Asian Development Bank: Manila, The Philippines, 2020.

31. Rada, E.C.; Ragazzi, M.; Torretta, V.; Castagna, G.; Adami, L.; Cioca, L.I. Circular Economy and Waste to Energy. AIP Conf. Proc. 1968, 030050, 2018. [CrossRef]

32. Bassi, S.A.; Christensen, T.H.; Damgaard, A. Environmental performance of household waste management in Europe-An example of 7 countries. Waste Manag. 2017, 69, 545-557. [CrossRef] 
33. Sala, D.; Bieda, B. The ThermalWaste Treatment Plant in Kraków, Poland: A Case Study. In Waste Power Plant; Intech Open: London, UK, 2019; pp. 1-18.

34. Scarlat, N.; Fahl, F.; Dallemand, J.-F. Status and Opportunities for Energy Recovery from Municipal Solid Waste in Europe. Waste Biomass Valoriz. 2018, 10, 2425-2444. [CrossRef]

35. Uctu, R.; Essop, H. Identifying the strength and weaknesses of the South African tech-based industries: Insights from the Swiss South African business development programme. Afr. J. Sci. Technol. Innovat. Dev. 2020, 12, 517-528. [CrossRef]

36. Pathak, S.; Muralidharan, E. A two-staged approach to technology entrepreneurship: Differential effects of intellectual property rights. Technol. Innovat. Manag. Rev. 2020, 10, 5-13. [CrossRef]

37. Wei, W.; Zhang, J. Research on the Development of New Technologies Based on New Magnetic Material Technology Entrepreneurship. IOP Conf. Ser. Earth Environ. Sci. 2020, 440, 022030. [CrossRef]

38. Giones, F.; Brem, A. Digital technology entrepreunership: A definition and research agenda. Technol. Innov. Manag. Rev. 2017, $7,27$.

39. Ferreira, J.J.; Ferreira, F.A.; Fernandes, C.I.; Jalali, M.S.; Raposo, M.L.; Marques, C.S. What do we not know about technology entrepreneurship research? Int. Entrepreneur. Manag. J. 2016, 12, 713-733. [CrossRef]

40. Adetayo, O.A. IT Entrepreneurship Technology Entrepreneurship: Trends, Opportunities, Challenges. 2019. Available online: https:/ / www.academia.edu/40796380/IT_Entrepreneurship_Technology_Entrepreneurship. (accessed on 4 February 2021).

41. Butler, J.S.; Garg, R.; Stephens, B. Social networks, funding, and regional advantages in technology entrepreneurship: An empirical analysis. Inform. Syst. Res. 2020, 31, 198-216. [CrossRef]

42. Solomon, P.; Aggarwal, T. Technology entrepreneurship in real estate sector development in India: PPP model. Ind. J. Fin. 2020, 14, 22-35. [CrossRef]

43. Neumeyer, X.; Santos, S.C. A lot of different flowers make a bouquet: The effect of gender composition on technology-based entrepreneurial student teams. Int. Entrepreneur. Manag. J. 2020, 16, 93-114. [CrossRef]

44. Chebo, A.K.; Wubatie, Y.F. Commercialisation of technology through technology entrepreneurship: The role of strategic flexibility and strategic alliance. Technol. Anal. Strat. Manag. 2020. [CrossRef]

45. Wyszomirski, A.; Olkiewicz, M. Environmental Corporate Social Responsibility as a tool for creating the future of environmental protection. Rocznik Ochrona Środowiska 2020, 22, 1145-1161.

46. Olkiewicz, M. Training of human resources as an element of development and building discipline. Sci. Pap. Siles. Univ. Technol. Organiz. Manag. Ser. 2020, 148, 593-604. [CrossRef]

47. Gajdzik, B. Envoronmental aspects, strategies and waste logistic system based on the example of metallurgical company. Metalurgija 2009, 48, 63-67.

48. Fayolle, A.; Lamine, W.; Mian, S.; Phan, P. Effective models of science, technology and engineering entrepreneurship education: Current and future research. J. Technol. Transfer 2020. [CrossRef]

49. Hussain, Z.; Mishra, J.; Vanacore, E. Waste to energy and circular economy: The case of anaerobic digestion. J. Enterpr. Inform. Manag. 2020, 33, 817-838. [CrossRef]

50. Urbano, D.; Guerrero, M.; Ferreira, J.J.; Fernandes, C.I. New technology entrepreneurship initiatives: Which strategic orientations and environmental conditions matter in the new socio-economic landscape? J. Technol. Transfer 2019, 44, 1577-1602. [CrossRef]

51. Langford, G.; Langford, T. Building a sustainable business model through technology entrepreneurship: An analysis of business models from a system and a system of systems perspective. In Proceedings of the PICMET 2019-Portland International Conference on Management of Engineering and Technology: Technology Management in the World of Intelligent Systems, Portland, OR, USA, 25-29 August 2019; p. 8893738.

52. Allen, J.P.; Paul Thomas, T.; Ford, J. Technology entrepreneurship in the digital age. In Proceedings of the SIGMIS-CPR 2019-Proceedings of the 2019 Computers and People Research Conference, Nashville, TN, USA, 20-22 June 2019; pp. 10-11.

53. Son, H.; Chung, Y.; Hwang, H. Do technology entrepreneurship and external relationships always promote technology transfer? Evidence from Korean public research organizations. Technovation 2019, 82-83, 1-15. [CrossRef]

54. Gitelman, L.D.; Kozhevnikov, M.V.; Starikov, E.M.; Rada, E.C. Scaling up the innovation process in the energy sector on the basis of technology entrepreneurship. WIT Trans. Ecol. Environ. 2019, 222, 1-12.

55. Beckman, C.; Eisenhardt, K.; Kotha, S.; Meyer, A.; Rajagopolan, N. The role of the entrepreneur in technology entrepreneurship. Strat. Entrepreuner. J. 2012, 6, 89-93. [CrossRef]

56. Jafari-Sadeghi, V.; Garcia-Perez, A.; Candelo, E.; Courtier, J. Exploring the impact of digital transformation on technology entrepreneurship and technological market expansion: The role of technology readiness, exploration and exploitation. J. Bus. Res. 2021, 124, 100-124. [CrossRef]

57. Eliakis, S.; Kotsopoulos, D.; Karagiannaki, A.; Pramatari, K. Survival and Growth in Innovative Technology Entrepreneurship: A Mixed-Method Investigation. Admin. Sci. 2020, 10, 39. [CrossRef]

58. Bailetti, T. Technology Entrepreneurship: Overview, Definition, and Distinctive Aspects. Technol. Innovat. Manag. Rev. 2012, 2, 5-12. [CrossRef]

59. Hejazi, S.R.; Seifollahi, M.R. A fuzzy-based roadmapping model for enhancing high-tech small firms' technological entrepreneurship capabilities: Cases of Iran. Technol. Anal. Strat. Manag. 2020, 32, 634-652. [CrossRef]

60. Badzińska, E. The Concept of Technological Entrepreneurship: The Example of Business Implementation. Entrepreneurial Bus. Econ. Rev. 2016, 4, 47-72. [CrossRef] 
61. De Waal, A.A. Characteristics of High Performance Organizations. Bus. Manag. Strat. 2012, 3, 28-45. [CrossRef]

62. Schreurs, M.; Meingast, A. A High Performance Organization ... What It is? HPO Centre: Amsterdam, The Netherlands, 2015.

63. Tajvidi, R.; Tajvidi, M. The growth of cyber entrepreneurship in the food industry: Virtual community engagement in the COVID-19 era. Br. Food J. 2020. [CrossRef]

64. Rujira, T.; Nilsook, P.; Wannapiroon, P. Synthesis of vocational education college transformation process toward high-performance digital organization. Int. J. Inform. Educ. Technol. 2020, 10, 832-837. [CrossRef]

65. Kirkman, B.L.; Kevin, B.L.; Young, D.P. High-Performance Work Organizations. Definitions, Practices and an Annotated Bibliography; Centre for Creative Leadership: Greensboro, NC, USA, 1999.

66. Do, T.T.; Mai, N.K. High-performance organization: A literature review. J. Strateg. Manag. 2020, 13, 297-309. [CrossRef]

67. Arshad, M.A.; Kalimullah Khan, S.; Shahid, Z. High performance organisation: The only way to sustain public sector organisations. Int. J. Public Sector Perform. Manag. 2020, 6, 806-816. [CrossRef]

68. Ariratana, W.; Ngang, T.K.; Sirisooksilp, S. The effect of innovative leadership on competency of creating high performance organization. Kasetsart J. Soc. Sci. 2019, 40, 311-318.

69. Honyenuga, B.Q.; Tuninga, R.S.J.; Ghijsen, P.W.T.H. Management innovation and organisational performance: The mediating role of high performance organisation framework. Int. J. Bus. Globalis. 2019, 22, 295-315. [CrossRef]

70. Mroueh, M.; de Waal, A. Is the high performance organization framework applicable to Takaful insurance companies? J. Islam. Account. Bus. Res. 2018, 9, 77-90. [CrossRef]

71. Kordel, P. Technology entrepreneurship attributes on enterprises from Aviation Valley in Poland: Fuzzy sets approach. In Proceedings of the European Conference on Innovation and Entrepreneurship, ECIE 2018, Aveiro, Portugal, 20-21 September 2018; pp. 366-374.

72. Katz, D.; Kahn, R.L. The Social Psychology of Organizations, 2nd ed.; Wiley: New York, NY, USA, 1978.

73. Meyer, A.D.; Tsui, A.S.; Hinings, C.R. Configurational Approaches to Organizational Analysis. Acad. Manag. J. 1993, 36, 1175-1195.

74. Fiss, P.C.; Marx, A.; Cambré, B. Configurational Theory and Methods in Organizational Research: Introduction. In Research in the Sociology of Organizations, Organizational Research: Introduction; Fiss, P.C., Cambré, B., Marx, A., Eds.; Configurational Theory and Methods in Organizational Research (Research in the Sociology of Organizations, Volume 38); Emerald Group Publishing Limited: Bingley, UK, 2013; pp. 1-22.

75. Ragin, C.C. The Comparative Method: Moving beyond Qualitative and Quantitative Strategies; University of California Press: Berkeley, CA, USA, 1987.

76. Ragin, C.C. Fuzzy Set Social Science; University of Chicago Press: Chicago, IL, USA, 2000.

77. Ragin, C.C. Redesigning Social Inquiry: Fuzzy Sets and Beyond; University of Chicago Press: Chicago, IL, USA, 2008.

78. Rihoux, B.; Marx, A. Qualitative comparative analysis at 25: State of play and agenda. Polit. Res. Quart. 2013, 66, 167-170. [CrossRef]

79. Schneider, C.Q.; Wagemann, C. Set-Theoretic Methods for the Social Sciences: A Guide to Qualitative Comparative Analysis; Cambridge University Press: Cambridge, UK, 2012.

80. Marx, A.; Rihoux, B.; Ragin, C. The origins, development and application of qualitative comparative analysis (QCA): The first 25 years. Eur. Polit. Sci. Rev. 2013. [CrossRef]

81. Fiss, P.C. Building better causal theories: A fuzzy set approach to typologies in organization research. Acad. Manag. J. 2011, 54, 393-420. [CrossRef]

82. Keunecke, M. Energy from waste -Improvements in energy efficiency. Waste Manag. 2016, 54, 1-2. [CrossRef] [PubMed]

83. Breeze, P. The Economics of Energy from Waste. Energy Waste 2018, 83-87. [CrossRef]

84. Psomopoulos, C.S.; Bourka, A.; Themelis, N.J. Waste-to-energy: A review of the status and benefits in USA. Waste Manag. 2009, 29, 1718-1724. [CrossRef]

85. Lauber, J.D.; Morris, M.E.; Ulloa, P.; Hasselriis, F. Local waste-to-energy vs. long distance disposal of municipal waste. In Proceedings of the AWMA Conference, New Orleans, LO, USA, 21 June 2006.

86. Chaliki, P.; Psomopoulos, C.S.; Themelis, N.J. WTE plants installed in European cities: A review of success stories. Manag. Environ. Qual. 2016, 27, 606-620. [CrossRef]

87. Themelis, N.J.; Diaz Barriga, M.E.; Estevez, P.; Velasco, M.G. Guidebook for the application of Waste-To-Energy technologies in Latin America and the Caribbean; Earth Engineering Center Interamerican Development Bank: New York, NY, USA, 2013.

88. Kumarasiri, D.M.G.T.; Dissanayke, D.M.P.P. Stateholders' involvement in successful implementation of waste to energy projects: Case studies in Sri Lanka Colombo, Sri Lanka. In Proceedings of the 8th World Construction Symposium, Colombo, Sri Lanka, 8-10 November 2019; pp. 535-546. [CrossRef]

89. Wen-Tien, T. An Analysis of Operational Efficiencies in the Waste-to-Energy (WTE) Plants of Kaohsiung Municipality (Taiwan). Resources 2019, 8, 125. [CrossRef]

90. Tsai, W.T.; Kuo, K.C. An analysis of power generation from municipal solid waste (MSW) incineration plants in Taiwan. Energy 2010, 35, 4824-4830. [CrossRef]

91. Tan, S.T.; Ho, W.S.; Hashim, H.; Lee, C.T.; Taib, M.R.; Ho, C.S. Energy, economic and environmental (3E) analysis of waste-toenergy (WTE) strategies for municipal solid waste (MSW) management in Malaysia. Energy Convers. Manag. 2015, 102, 111-120. [CrossRef] 
92. Zhao, X.G.; Jiang, G.W.; Li, A.; Wang, L. Economic analysis of waste-to-energy industry in China. Waste Manag. 2016, 48, 604-618. [CrossRef] [PubMed]

93. Grosso, M.; Motta, A.; Rigamonti, L. Eficiency of energy recovery from waste incineration, in the light of the new Waste Framework Directive. Waste Manag. 2010, 30, 1238-1243. [CrossRef]

94. Perkoulidis, G.; Kasampalis, T.; Karagiannidis, L.; Moussiopoulos, N. Development of waste-to-energy plants database for evaluating the efficiency of energy recovery from waste in Europe. Waste Biomass Valor. 2015, 6, 983-988. [CrossRef]

95. Muller, D.; Wollmer, S.; Aßbichler, D.; Murer, M.J.; Heuss-Aßbichler, S.; Rieger, K.; Hill, H.; Hartel, C.; Masset, P.J. High temperature corrosion studies of a zirconia coating: Implications for waste-to-energy (WTE) plants. Coatings 2016, 6, 36. [CrossRef]

96. Smol, M.; Duda, J.; Czaplicka-Kotas, A.; Szołdrowska, D. Transformation towards Circular Economy (CE) in Municipal Waste Management System: Model Solutions for Poland. Sustainability 2020, 12, 4561. [CrossRef]

97. CEWP. Confederation of European Waste-to-Energy Plants. Available online: https://www.cewep.eu/what-cewep-does/ (accessed on 19 June 2021).

98. Waste-To-Energy Sustainability Roadmap Towards 2035, CEWEP. 2019. Available online: https://www.cewep.eu/wp-content/ uploads/2019/09/WtE_Sustainability_Roadmap_Digital.pdf (accessed on 19 June 2021).

99. Waste-To-Energy: Energising Your Waste. Available online: https://www.cewep.eu/wp-content/uploads/2018/07/Interactivepresentation-2018-New-slides.pdf (accessed on 19 June 2021).

100. Industry Barometr Waste-To-Energy 2020, CEWP. 2020. Available online: https://www.cewep.eu/wp-content/uploads/2020/0 9/Industry-barometer-WtE-2020.pdf (accessed on 19 June 2021).

101. Vujic, G.; Stanisavljevic, N.; Batinic, B.; Jurakic, Z.; Ubavin, D. Barriers for implementation of "waste to energy" in developing and transition countries: A case study of Serbia. Mater. Cycles Waste Manag. 2017, 19, 55-69. [CrossRef]

102. Waste Framework Directive, Directive 2018/851 of the European Parliament and the Council on Amending Directive 2008/98/EC on Waste. Available online: https:/ / eur-lex.europa.eu/legal-content/EN/TXT/?uri=celex\%3A32018L0851 (accessed on 19 June 2021).

103. Landfill Directive, Directive 2018/850 of the European Parliament and of the Council Amending Directive 1999/31/EC on the Landfill of Waste. Available online: https:/ / eur-lex.europa.eu/legal-content/EN/TXT/?uri=celex\%3A32018L0850 (accessed on 19 June 2021).

104. The European Green Deal. 2020. Available online: https://eur-lex.europa.eu/legal-content/EN/TXT/?uri=CELEX\%3A52019 DC0640\&qid=1605784676826 (accessed on 19 June 2021).

105. The Circular Economy Action Plan. 2020. Available online: https:/ /eur-lex.europa.eu/legal-content/EN/TXT/?uri=CELEX\% 3A52020DC0098\&qid=1605784799739 (accessed on 19 June 2021).

106. Beckman, C.; Eisenhardt, K.; Kotha, S.; Meyer, A.; Rajagopolan, N. Special Issue Technology Entrepreneurship. Strat. Entrepreneur. J. 2012. [CrossRef]

107. Mosey, S.; Noke, H.; Kirkham, P. Building an Entrepreneurial Organization; Routledge: London, UK, 2017.

108. Robbins, S.P.; Judge, T.A.; Campbell, T.T. Organizational Behaviour; Pearson: London, UK, 2010.

109. Gupta, V.; MacMillan, I.C.; Surie, G. Entrepreneurial Leadership: Developing and Measuring a Crosscultural Construct. J. Bus. Vent. 2004, 241-260. [CrossRef]

110. Waddell, B.D.; Roberto, M.A.; Yoon, S. Uncovering Hidden Profiles: Advocacy in Team Decision Making. Manag. Decis. 2013, 321-340. [CrossRef]

111. Pinho, C.S.B.; Ferreira, J.J. Impact of information technologies, corporate entrepreneurship and innovation on the organizational performance: A literature review. Int. J. Soc. Ecol. Sustain. Dev. 2017, 8, 32-48. [CrossRef]

112. Hardill, I.; Wynarczyk, P. Technology, entrepreneurship and company performance in textile and clothing SMEs. New Technol. Work Employ. 1996, 11, 107-117. [CrossRef]

113. Jaksić, M.L.; Jovanović, M.; Petković, J. Technology entrepreneurship in the changing business environment-A triple helix performance model. Amfiteatru Econ. 2015, 17, 422-440.

114. Pikoń, K.; Poranek, N.; Czajkowski, A.; Łaźniewska-Piekarczyk, B. Poland's Proposal for a Safe Solution of Waste Treatment during the COVID-19 Pandemic and Circular Economy Connection. Appl. Sci. 2021, 11, 3939. [CrossRef]

115. Douglas, E.J.; Shepherd, D.A.; Prentice, C. Using fuzzy-set qualitative comparative analysis for a finer-grained understanding of entrepreneurship. J. Bus. Vent. 2020, 1, 1-17. [CrossRef]

116. Murthy, P. Fuzzy Logical Techniques in Social Science Research-Application and Adoption, Murthy, Psr, Fuzzy Logical Techniques in Social Science Research-Application and Adoption. 2019. Available online: https: / /ssrn.com/abstract=3394030 or http:/ / dx.doi.org/10.2139/ssrn.3394030 (accessed on 24 May 2021).

117. Ragin, C.C. Set Relations in Social Research: Evaluating Their Consistency and Coverage. Polit. Anal. 2006, 14, 291-310. [CrossRef]

118. Bratianu, C. Strategic Thinking in Turbulent Times. In Proceedings of the 11th International Conference on Business Excellence, Bucharest, Romania, 22-23 March 2017. [CrossRef]

119. Jiang, P.; Fan, Y.V.; Klemeš, J. Impacts of COVID-19 on energy demand and consumption: Challenges, lessons and emerging opportunities. Appl. Energy 2021, 285, 116441. [CrossRef] [PubMed]

120. Nakat, Z.; Bou-Mitri, C. COVID-19 and the food industry: Readiness assessment. Food Control 2021, 121, 107661. [CrossRef] [PubMed] 
121. Gregurec, I.; Furjan, M.T.; Tomičić-Pupek, K. The impact of covid-19 on sustainable business models in smes. Sustainability 2021, 13, 1098. [CrossRef]

122. Bak, P.; Kapusta, M.; Sukiennik, M. Mining Company Management in Case of the Epidemic Emergency. J. Pol. Min. Eng. Soc. 2020, 2, 231-235.

123. Karunathilake, K. Positive and negative impacts of COVID-19, an analysis with special reference to challenges on the supply chain in South Asian countries. J. Soc. Econ. Dev. 2020. [CrossRef]

124. Donthu, N.; Gustafsson, A. Effects of COVID-19 on business and research. J. Bus. Res. 2020, 17, 284-289. [CrossRef]

125. Ozli, P.K.; Arun, T.G. Spillover of COVID-19: Impact on the Global Economy. SSRN Electron. J. 2020. [CrossRef]

126. Ayache, Z.; Naima, G. The Impact of Flexible Benefits Plan on Organization Commitment and Intention to Quit. Medit. J. Soc. Sci. 2014, 5, 136-145. [CrossRef]

127. Augostin-Egole, I.S.; Iheriohanma, E.B.J.; Nwokorie, C. Flexible Working Arrangements and Organizational Performance: An Overview. J. Human. Soc. Sci. 2020, 25, 50-58. [CrossRef]

128. Sarkodie, S.A.; Owusu, P.A. Impact of COVID-19 pandemic on waste management. Environ. Dev. Sustain. 2020. [CrossRef]

129. Tripati, A.; Taygi, V.K.; Vivekanad, V.; Bose, P.; Suthar, S. Challenges, opportunities and progress in solid waste management during COVID-19 pandemic. Case Stud. Chem. Environ. Eng. 2020, 2, 100060. [CrossRef]

130. Fan, Y.F.; Jiang, P.; Hemzal, M.; Klemeš, J. An update of COVID-19 influence on waste management. Sci. Total Environ. 2020, 1, 754. [CrossRef]

131. Chen, S.; Duanxu, W. High performance work systems and organizational innovative capabilities in the PRC: The mediating role of intellectual capital. In Proceedings of the PICMET 2010 Technology Management for Global Economic Growth, Phuket, Thailand, 12-22 July 2010.

132. Li, W.; Bhutto, T.A.; Nasiri, A.R.; Ali, F. Organizational innovation: The role of leadership and organizational culture. Int. J. Public Leader. 2017, 14. [CrossRef]

133. Khasawenh, S.; Al-Zawahreh, A. High-performance work practices, innovation and perceived organizational performance: Evidence from the Jordanian service sector. Afr. J. Bus. Manag. 2012, 6, 3320-3326.

134. Scherer, F.M.; Ross, D. Industrial Market structure and Economic Performance; Houghton Mifflin: Boston, MA, USA, 1990.

135. Kyriakis, E.; Psomopoulos, C.; Kokkotis, P.; Bourtsalas, A.; Themelis, N. A step by step selection method for the location and the size of a waste-to-energy facility targeting the maximum output energy and minimization of gate fee. Environ. Sci. Pollut. Res. 2018, 25, 26715-26724. [CrossRef] [PubMed]

136. Kyriakis, E.; Psomopoulos, C.; Kalkanis, K. Investigating the Correlation of Purchase Power Parity (PPP) with the Adopted Waste Management Method in EU28. Soc. Sci. 2019, 8, 162. [CrossRef]

137. Levaggi, L.; Levaggi, R.; Marchiori, C.; Trecroci, C. Waste-to-Energy in the EU: The Effects of Plant Ownership, Waste Mobility, and Decentralization on Environmental Outcomes and Welfare. Sustainability 2020, 12, 5743. [CrossRef]

138. Schiffer, H.-W.; Westhuizen, Z.; Radu, C.; Ibeanu, N.; Marshall, J.; Hoornweg, D.; Itodo, I. World Energy Resources Waste to Energy; World Energy Council: London, UK, 2016.

139. Carlton, D.W.; Perloff, J.M. Modern Industrial Organization; Addison-Wesley: Boston, MA, USA, 2000.

140. Kwoka, J.E. The effect of market share distribution on industry performance. Rev. Econ. Stat. 1979, 61, 101-109. [CrossRef] 